Abstract-Identifying effective methods of reducing shark bycatch in hook-based fisheries has received little attention despite reports of declines in some shark populations. Previously proposed shark bycatch mitigation measures include gear modifications, time and area closures, avoidance of areas with high shark abundance, use of repellents, and use of specific bait types. Regardless of the method of shark bycatch reduction, knowledge of the effects of the chosen method on the catch rates of targeted fish species should be understood. To examine the effects of bait type on catch rates of sharks and teleosts on bottom longline gear, standardized gear was deployed with bait alternating between Atlantic mackerel (Scomber scombrus) and northern shortfin squid (Illex illecebrosus). For all shark species examined, except the scalloped hammerhead (Sphyrna lewini), a preference for hooks baited with Atlantic mackerel was observed. Commercially and recreationally important teleosts had no significant preference for a specific bait, with the exception of the red drum (Sciaenops ocellatus), which had a significant preference for hooks baited with northern shortfin squid. Bait preference decreased as total catch rate increased on individual longline sets. Our results point to the use of specific baits as a viable method to reduce shark catch rates without decreasing catches of targeted teleosts.

Manuscript submitted 10 November 2015. Manuscript accepted 27 October 2016.

Fish. Bull. 115:50-59 (2017).

Online publication date: 10 November 2016. doi: 10.7755/FB.115.1.5

The views and opinions expressed or implied in this article are those of the author (or authors) and do not necessarily reflect the position of the National Marine Fisheries Service, NOAA.

\title{
Influence of bait type on catch rates of predatory fish species on bottom longline gear in the northern Gulf of Mexico
}

\author{
William B. Driggers III (contact author) ${ }^{1}$ \\ Matthew D. Campbell ${ }^{1}$ \\ Kristin M. Hannan² \\ Eric R. Hoffmayer ${ }^{1}$ \\ Christian M. Jones ${ }^{1}$ \\ Lisa M. Jones ${ }^{1}$ \\ Adam G. Pollack ${ }^{2}$ \\ Email address for contact author: william.driggers@noaa.gov \\ 1 Mississippi Laboratories \\ Southeast Fisheries Science Center \\ National Marine Fisheries Service, NOAA \\ P.O. Drawer 1207 \\ Pascagoula, Mississippi 39567 \\ 2 Riverside Technology Inc. \\ Mississippi Laboratories \\ Southeast Fisheries Science Center \\ National Marine Fisheries Service, NOAA \\ P.O. Drawer 1207 \\ Pascagoula, Mississippi 39567
}

Because of reported declines in some shark populations, there has been increasing interest in mitigating bycatch rates of shark species in longline fisheries that target teleosts (Francis et al., 2001; Beerkircher et al., 2002; Gilman et al., 2008; Ward et al., 2008). Within the northern Gulf of Mexico, commercial fishing for sharks has occurred since the 1920s (Rogers, 1920) and continues to present day. Although directed commercial fishing effort for sharks in the region has waxed and waned over the years, shark bycatch continues to be an important source of mortality, particularly in hook-based fisheries, such as the snapper and grouper bottom longline fishery (e.g., Scott-Denton et al., 2011).

Proposed or enacted efforts to curtail shark bycatch in longline fisheries have included gear modifications
(Ward et al., 2008), reductions in gear soak time (Carruthers et al., 2011), adjustments in fishing depth (Rey and Muñoz-Chápuli, 1991), time and area closures (Watson et al., 2009), avoidance of areas of known high shark abundance (Walsh et al., 2009), use of repellents (Robbins et al., 2011) and use of specific bait types (Gilman et al., 2007). Ultimately, for any bycatch reduction method to be fully embraced within a fishery, it will be necessary that catch rates of targeted species not be negatively affected when a specific approach is applied. Ideally, a bycatch reduction approach would minimize bycatch rates and not affect catch rates of target species and cause the least amount of economic hardship and changes to proven fishing practices. Among measures proposed to mitigate shark bycatch, use of bait that 
does not decrease catch rates of target species yet reduces rates of shark capture could be the most easily implemented and likely to be readily accepted within a fishery.

Past studies have shown that catch rates of certain shark species are affected by the use of specific bait types. For example, Gilman et al. (2007) analyzed data collected in the pelagic longline fishery in Hawaii and determined that the catch rate of blue sharks (Prionace glauca) was reduced by $36 \%$ when fish, rather than squid, were used as bait. Similarly, Watson et al. (2005) conducted experimental longline sets in the western North Atlantic Ocean and found catch rates of blue sharks were $31-40 \%$ (depending on hook type) lower on hooks baited with fish than on hooks baited with squid. Although results of these studies are potentially biased by use of multiple hook types and sizes, their results strongly indicate that use of a specific bait type could be a means to reduce bycatch of sharks.

Hook-based fisheries in the northern Gulf of Mexico that target grouper (Serranidae), snapper (Lutjanidae), and tilefish (Malacanthidae) species frequently capture sharks (Gulak et al., 2013). For example, the Atlantic sharpnose shark (Rhizoprionodon terraenovae) was the sixth-most captured fish species among the approximately 180 fish species reported in observer data collected from the bottom longline fishery for reef fish in the Gulf of Mexico (Scott-Denton et al., 2011). Furthermore, smoothhound (Mustelus spp.) and blacknose (Carcharhinus acronotus) sharks were among the 20 most frequently captured fish taxa within the same fishery (Scott-Denton et al., 2011). The size and type of hooks vary in the bottom longline fishery for reef fish in the Gulf of Mexico (Gulak et al., 2013), and bait type is inconsistent, depending on personal preference, availability, and price, among other factors (Prytherch, 1983; Scott-Denton et al., 2011). Because there is high variability in the gear and bait used within this fishery, use of observer data to examine potential effects of bait type on the catch rates of specific species is problematic. Our goal was to conduct a controlled experiment to test the effects of 2 readily available bait types commonly used in the bottom longline fishery for reef fish on catch rates of sharks and economically important teleosts in this region. Additionally, we examined density-dependent effects on preferences for the 2 bait types for both groups of fish species.

\section{Materials and methods}

Bottom longline gear was deployed from the NOAA Ship Oregon II at sampling sites in the northern Gulf of Mexico from 11 March through 13 April 2015. Sampling sites were selected on the basis of $18.5-\mathrm{km}$ grids within predefined geographic areas (from Pascagoula, Mississippi, to Cape San Blas, Florida) and depth (9-1000 m) constraints. However, obstructions (e.g., other vessels, reefs, petroleum platforms, and safety fairways) caused the locations of some sampling sites to be different from the positions that were originally planned. The bounds of the sampling universe were selected to maximize sampling opportunities within temporal limitations.

Bottom longline gear consisted of $1842 \mathrm{~m}$ of $4.0-\mathrm{mm}$ monofilament mainline and 100 gangions. Each gangion was $3.7 \mathrm{~m}$ in length and constructed of an AK snap (size 150), $3.2 \mathrm{~m}$ of 3.0-mm-diameter monofilament, 0.5 $\mathrm{m}$ of 2.4-mm-diameter fishing wire, and a $15 / 0$ circle hook (Mustad \#39960D ${ }^{1}$, O. Mustad \& Son A.S, Gjörvik, Norway). Each gangion was baited with Atlantic mackerel (Scomber scombrus) or northern shortfin squid (Illex illecebrosus). Both bait types were cut so that they were of the same approximate dimensions and appropriately sized for the hook. Gangions were deployed so that each bait type alternated along the length of the mainline (i.e., northern shortfin squid, Atlantic mackerel, northern shortfin squid, Atlantic mackerel), and the starting bait type was selected randomly for each longline set.

Gear soak time, defined as time elapsed between deployment of the terminal high flyer during gear deployment and retrieval of the first high flyer during haulback, was approximately $1 \mathrm{~h}$ at sampling sites with depths less than $400 \mathrm{~m}$ and $2 \mathrm{~h}$ at sampling sites with depths greater than $400 \mathrm{~m}$. However, the actual time each hook spends in the water can vary due to a number of factors, such as hook position along the mainline, differences in gear setting and retrieving speeds, and delays related to handling times that were associated with the number of organisms captured. Therefore, the time each hook entered the water at deployment and exited the water during retrieval was electronically monitored. The elapsed time between deployment and retrieval of each hook was considered hook soak time.

The status of each retrieved hook was monitored and recorded as whole bait present, partial bait present, no bait present, missing hook, or organism captured. To determine whether baits of Atlantic mackerel and northern shortfin squid were retained equally on hooks, data from gangions classified with a status of whole bait present were compared by using chi-square tests with Yates correction for continuity. Using the same test, we investigated potential differences in bait retention between Atlantic mackerel and northern shortfin squid when there were hook interactions with feeding organisms other than those retained on a hook. For this investigation, the categories partial bait present and no bait present were combined. We combined them because of the subjective nature of the partial bait present category (i.e., the status of a hook was classified the same whether, for example, a small piece of bait tissue had been removed or most of the bait had been removed). The category missing hook was not included in analyses because, in the limited number of cases for which this status was recorded, the hook

\footnotetext{
1 Mention of trade names or commercial companies is for identification purposes only and does not imply endorsement by the National Marine Fisheries Service, NOAA.
} 


\section{Table 1}

Catch composition and length ranges, by bait type, of fish species caught on bottom longline gear in the northern Gulf of Mexico in March and April 2015. The bait types are Atlantic mackerel (Scomber scombrus) and northern shortfin squid (Illex illecebrosus). All measurements are reported in fork length, with the exceptions of values for tilefish (Lopholatilus chamaeleonticeps) and red drum (Sciaenops ocellatus) that are reported in total length, as well as values for clearnose skates (Raja eglanteria) that are reported in disc width. Results of Kolmogorov-Smirnov (K-S), Mann-Whitney (M-W), and chi-square (with Yates correction) tests, used to test for differences in species-specific length distributions, median lengths, and catch rates between bait types, respectively, are provided with associated $P$-values.

\begin{tabular}{|c|c|c|c|c|c|c|c|}
\hline \multirow[b]{2}{*}{ Species } & \multicolumn{2}{|c|}{ Atlantic mackerel } & \multicolumn{2}{|c|}{ Northern shortfin squid } & \multirow{2}{*}{$\begin{array}{l}\mathrm{K}-\mathrm{S} \\
(P)\end{array}$} & \multirow{2}{*}{$\begin{array}{c}\mathrm{M}-\mathrm{W} \\
(P)\end{array}$} & \multirow{2}{*}{$\begin{array}{c}\text { Chi- } \\
\text { square }(P)\end{array}$} \\
\hline & $n$ & size range $(\mathrm{mm})$ & $n$ & size range $(\mathrm{mm})$ & & & \\
\hline Carcharhinus acronotus & 61 & $563-1053$ & 12 & $587-1061$ & $1.19(0.12)$ & $238.0(0.06)$ & $31.56(<0.01)$ \\
\hline Carcharhinus plumbeus & 45 & 1025-1800 & 7 & 1183-1546 & $0.95(0.33)$ & $98.0(0.13)$ & $26.33(<0.01)$ \\
\hline Centrophorous uyato & 43 & 610-951 & 21 & $478-948$ & $0.77(0.59)$ & $419.5(0.65)$ & $6.89(<0.01)$ \\
\hline Galeocerdo cuvier & 20 & $910-2620$ & 10 & $785-1812$ & $1.12(0.16)$ & $52.5(0.05)$ & $2.70(0.10)$ \\
\hline Hyporthodus flavolimbatus & 14 & $593-865$ & 6 & $560-795$ & $0.62(0.83)$ & $31.5(0.83)$ & $2.45(0.12)$ \\
\hline Lopholatilus chamaeleonticeps & 12 & $497-895$ & 14 & $465-905$ & $0.70(0.72)$ & $97.0(0.52)$ & $0.04(0.85)$ \\
\hline Lutjanus campechanus & 56 & $370-876$ & 45 & $536-860$ & $0.55(0.92)$ & $1208.0(0.89)$ & $0.99(0.32)$ \\
\hline Mustelus canis & 18 & $754-1187$ & 6 & $810-1081$ & $0.86(0.45)$ & $39.0(0.42)$ & $5.04(0.02)$ \\
\hline Mustelus sinusmexicanus & 40 & $686-1167$ & 24 & $713-1120$ & $0.76(0.62)$ & $379.0(0.34)$ & $3.52(0.06)$ \\
\hline Raja eglanteria & 7 & $384-410$ & 16 & $349-446$ & $0.78(0.57)$ & $47.0(0.97)$ & $2.78(0.09)$ \\
\hline Rhizoprionodon terraenovae & 344 & $574-895$ & 139 & $486-860$ & $0.69(0.73)$ & $21,969.0(0.80)$ & $86.16(<0.01)$ \\
\hline Sciaenops ocellatus & 5 & $825-910$ & 21 & $838-1005$ & $1.32(0.06)$ & $82.0(0.06)$ & $8.65(<0.01)$ \\
\hline Sphyrna lewini & 12 & $860-1890$ & 9 & $750-1860$ & $1.13(0.14)$ & $78.0(0.09)$ & $0.19(0.66)$ \\
\hline Squalus complex & 21 & $410-680$ & 10 & $445-655$ & $0.64(0.80)$ & $89.5(0.66)$ & $3.22(0.07)$ \\
\hline
\end{tabular}

could have been hung on the bottom and, as a result, gear failure could have occurred during retrieval. Additionally, to determine whether retention of the 2 bait types differed with increasing soak time, the distribution of hook soak times for hooks retrieved with whole bait present of Atlantic mackerel was compared to the distribution of soak times for hooks retrieved with whole bait present of northern shortfin squid by using a Kolmogorov-Smirnov test.

All captured individuals were identified to the lowest possible taxonomic level and measured to the nearest millimeter. Fork length (FL) and total length (TL) were measured from the tip of the rostrum to the caudal notch and to the tip of the upper lobe of the caudal fin while the fin was fully extended, respectively. For batoids, disc width was measured between apices of the pectoral fins. Species-specific identifications were not possible in a limited number of instances as a result of a fish escaping a hook before being landed (i.e., catch was confirmed but identification was not possible). In those cases, all individuals could be identified to at least the family level. A Kolmogorov-Smirnov test was used to test for differences in the species-specific length distributions of individuals caught on each bait type. When length distribution data of a species were normally distributed (as indicated by values of kurtosis and skewness being between -2 and 2) and homoscedastic (as assessed with an $F$-test), a $t$-test was used to determine whether differences existed in species-specific mean length at capture for each bait type. When length distribution data failed to meet the assumptions of parametric statistics, a Mann-Whitney $W$ test was used to compare median length of each species caught by bait type.

Chi-square tests with Yates correction for continuity were used to determine whether there was a bait-related effect on species-specific catch rates. Species included in analyses were limited to those that had a minimum of 20 individuals captured regardless of bait type (Table 1). Additionally, because of low species-specific capture rates and the close morphological similarities of the Cuban dogfish (Squalus cubensis) and the shortspine spurdog ( $S$. mitsukurii) (both species with fewer than 20 individuals captured), these squalid shark species were treated as a complex. For those species that showed a significant bait preference and were captured on a minimum of 10 longline sets, we examined if there was a change in the degree of bait preference with increasing total catch. For this examination, an index of bait preference (IBP) was calculated with the following equation:

\section{$I B P=($ number of individuals captured on mackerel - number of individuals captured on squid) / total number of individuals captured.}

The IBP values ranged from 1 (all individuals captured with Atlantic mackerel bait) to -1 (all individuals captured with northern shortfin squid bait). The value of 0 indicated that an equal number of individuals were caught on both bait types. To obtain a nonparametric estimation of the relationship between species-specific IBP and total catch, a locally weighted scatterplot 


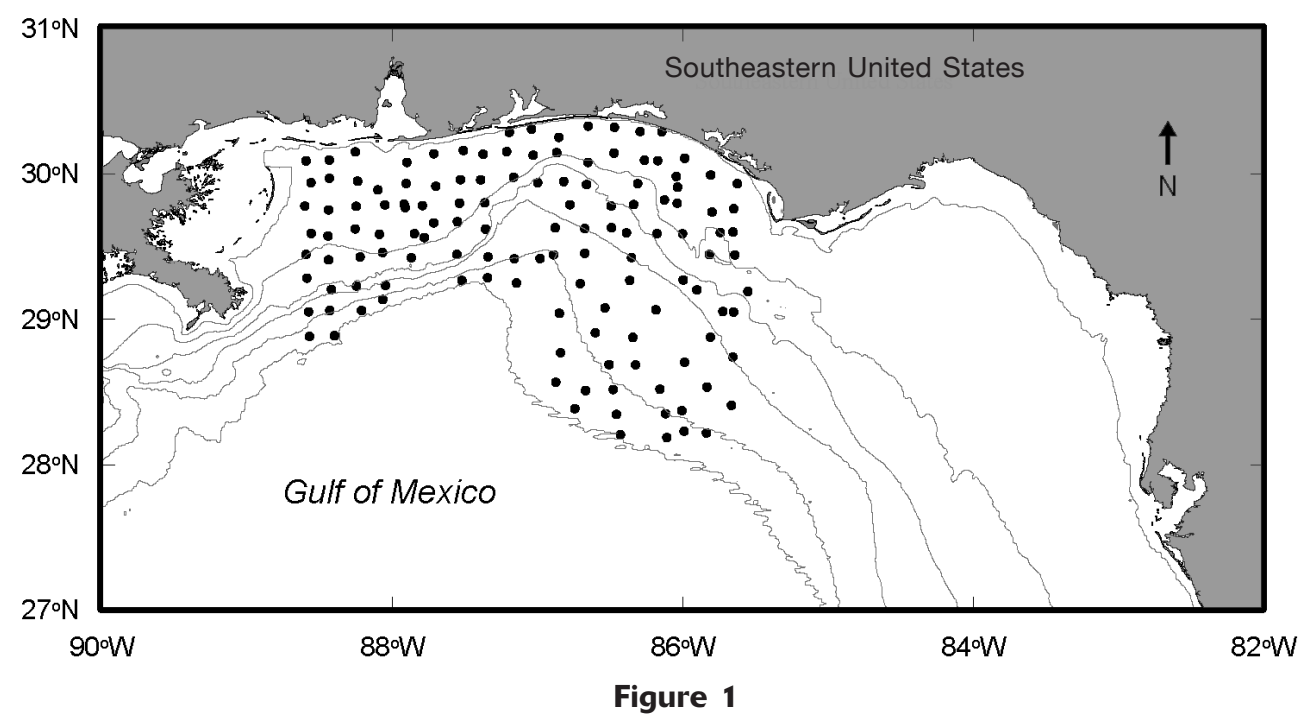

Map of sites where sampling was conducted with bottom longline gear in the northern Gulf of Mexico in March and April 2015. Black circles represent each sampling site. The grey lines indicate the isobaths at 10,50, 100, 200, 500, and $1000 \mathrm{~m}$.

smoothing (LOWESS) with a $75 \%$ smoothing factor was applied to scatterplots to determine whether a trend was present in the relationship. All statistical tests were considered significant at an $\alpha$ level of 0.05 .

\section{Results}

During March and April 2015, 131 longline sets were completed (Fig. 1) for this study, resulting in deployments of 13,100 hooks and the capture of 1196 individual fish. Hook soak times ranged from 77 to $257 \mathrm{~min}$ (mean of $118.6 \mathrm{~min}$, standard deviation [SD] 39.4), and hook-specific bait status was recorded for 12,888 gangions. Bait status of 212 hooks was not recorded due to technical difficulties; however, these hooks represented less than $2 \%$ of the gangions deployed. Of the monitored hooks, 8 were retrieved with the hook missing as a result of crimp failure (e.g. splitting or slipping). Of the 1944 gangions that were retrieved with whole bait present, there was no significant difference in the number of Atlantic mackerel $(n=956)$ and northern shortfin squid ( $n=988$ ) retained on hooks $\left(\chi^{2}=0.49, P=0.48\right)$. This result indicates that both bait types were equally retained on hooks during deployment, soak, and retrieval in the absence of interactions with feeding organisms. Interactions between bait and feeding organisms were evident on 9742 gangions that were retrieved with partial or no bait remaining on hooks. In these cases, bait damage or loss was more common with northern shortfin squid $(n=5033)$ than with Atlantic mackerel ( $n=4709) \quad\left(\chi^{2}=10.71, P<0.01\right)$. There was no significant difference in the distributions of hook soak times when hooks were retrieved with whole bait present (Kolmogorov-Smirnov statistic $=0.97, P=0.31$ ) (Fig. 2).

All captured organisms were fish species with the exception of 1 loggerhead sea turtle (Caretta caretta), captured with bait of northern shortfin squid, and 1 giant isopod, Bathynomus giganteus, captured with Atlantic mackerel. The total catch and size range of each species analyzed are presented in Table 1 . There were no significant differences in species-specific length distributions for individuals caught by bait type ( $P$-values for all species were $>0.05$ ) (Table 1 ), and length distribution data were non-normal or heteroscedastic, with the exception of data for the red drum. The mean size of red drum captured on hooks baited with Atlantic mackerel (mean: $859.0 \mathrm{~mm}$ TL [SD 32.1]) was significantly smaller than the mean size of individuals captured with northern shortfin squid (mean: $903.7 \mathrm{~mm}$ TL [SD 40.0]) $(t=-2.31, P=0.03)$.

There was a significant difference in the median length of tiger sharks (Galeocerdo cuvier) captured on each bait type, with the median length of tiger sharks being smaller on hooks baited with northern shortfin squid (1337 mm FL) than on hooks baited with Atlantic mackerel (1922 mm FL) $(W=52.5, P=0.05)$. There were no statistically significant species-specific differences in the median length of any other species between the 2 bait types at $\alpha=0.05$ (Table 1 ). However, at an $\alpha$ level of 0.10 , there were significant differences in the median length of blacknose sharks ( $W=238.0, P=0.06)$ and scalloped hammerheads (Sphyrna lewini) $(W=78.0, P=0.09)$ captured on the 2 bait types. For blacknose sharks, median length at capture was smaller when these sharks were caught with northern shortfin squid (1073 mm FL versus $1120 \mathrm{~mm}$ FL), whereas for scalloped hammerheads the median length at capture was smaller when these sharks were caught with Atlantic mackerel (1443 mm FL versus $1812 \mathrm{~mm}$ FL).

The results of chi-square tests indicate significant differences in the expected and observed catches for 5 shark and 1 teleost species (Table 1). All of the shark species for which a statistically significant preference 
for a single bait type was observed were captured more frequently with Atlantic mackerel than with northern shortfin squid. For example, sandbar sharks (Carcharhinus plumbeus) were caught 6.4 times more frequently with Atlantic mackerel than with northern shortfin squid. Furthermore, for those shark species that showed no statistically significant preference for a specific bait type, all were captured more frequently on hooks baited with Atlantic mackerel, and chi-square test $P$-values were $\leq 0.10$, with the exception of the value for the scalloped hammerhead $(P=0.66)$.

Unlike other elasmobranchs, clearnose skates (Raja eglanteria) were caught more frequently on hooks baited with northern shortfin squid; however, there was no statistically significant difference in the observed and expected catch of this species between the 2 bait types $\left(\chi^{2}=2.78, P=0.09\right)$. Among teleosts, red drum was the only species for which a significant bait preference $\left(\chi^{2}=8.65, P<0.01\right)$ was observed, and this species was caught 4.2 times more frequently with northern shortfin squid than with Atlantic mackerel. Other commercially and recreationally important teleosts that were captured include red snapper (Lutjanus campechanus) $\left(\chi^{2}=0.99, P=0.32\right)$ and tilefish (Lopholatilus chamaeleonticeps) $\left(\chi^{2}=0.04\right.$, $P=0.85$ ), neither of which had an observed significant bait preference. Although a significant bait preference was not found for yellowedge grouper (Hyporthodus flavolimbatus) $\left(\chi^{2}=2.45, P=0.12\right), 70 \%$ of all individuals of this species were captured on hooks baited with Atlantic mackerel.

The relationship between IBP and total catch was examined for Atlantic sharpnose shark, blacknose shark, sandbar shark, and red snapper. For all 3 shark species, a preference for hooks baited with Atlantic mackerel was observed at low rates of total catch; however, as catch rates increased, IBP values trended toward 0 (Fig. 3). This trend was most evident for sandbar sharks, which were captured exclusively on hooks baited with Atlantic mackerel when the total catch consisted of 12 of fewer fish (Fig. 3). A preference for hooks baited with Atlantic mackerel also was observed for red snapper at low rates of total catch; however, unlike what was observed for sharks, red snapper were captured regularly on hooks baited with northern shortfin squid regardless of total catch size (Fig. 3). Furthermore, when more than 20 individuals were captured on a longline set, red snapper were captured exclusively on hooks baited with northern shortfin squid (Fig. 3).

\section{Discussion}

The results of our study indicate that when given the choice between hooks baited with northern shortfin squid or with Atlantic mackerel, the degree of bait pref-

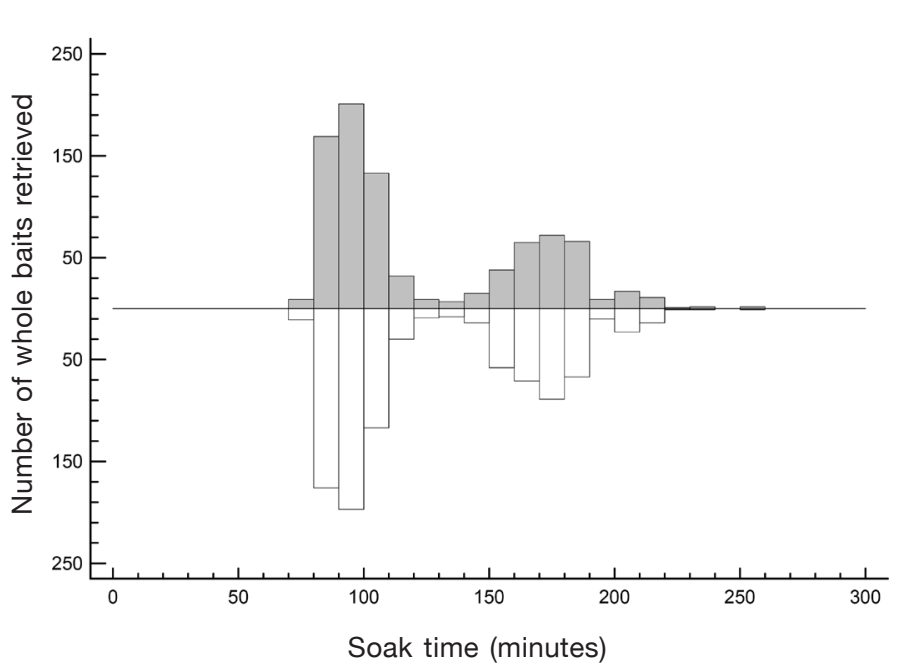

Figure 2

Comparison by bait type of the number of hooks retrieved with whole bait present over the range of hook soak times used in this study for which predatory fish species were caught on bottom longline gear in the northern Gulf of Mexico during March and April 2015. Gray bars represent the bait that was Atlantic mackerel (Scomber scombrus) and white bars represent the bait that was northern shortfin squid (Illex illecebrosus). erence varies among fish species and that, when present, bait preference generally declines with increasing rates of total catch on longline gear. Specifically, shark species commonly captured as bycatch on longline gear in the northern Gulf of Mexico preferentially selected Atlantic mackerel over northern shortfin squid, particularly when total catch rates were low. Although a statistically significant preference for hooks baited with Atlantic mackerel was documented only for the Atlantic sharpnose shark, blacknose shark, sandbar shark, smooth dogfish (Mustelus canis), and little gulper shark (Centrophorous uyato), the same trend was evident for all elasmobranch species captured, with the exceptions of the scalloped hammerhead and clearnose skate. There was no difference between the 2 bait types in catch rates, and therefore no difference in bait preference, for economically important teleosts, with the exception of the red drum. Together, these results provide support for an easily applied measure to reduce rates of shark bycatch and cause no effect on catch rates of target species or need for gear modifications.

Several previous studies reported declines in catch rates of blue sharks that were associated with specific bait types (Watson et al., 2005; Gilman et al., 2007; Foster et al., 2012) and found that bycatch of blue sharks was reduced when fish rather than squid were used as bait. Although our findings superficially seem in opposition to those of Watson et al. (2005) and Gilman et al. (2007), differences among the studies can be explained by the diets of the species examined and, therefore, support the use of specific bait types to re- 
A

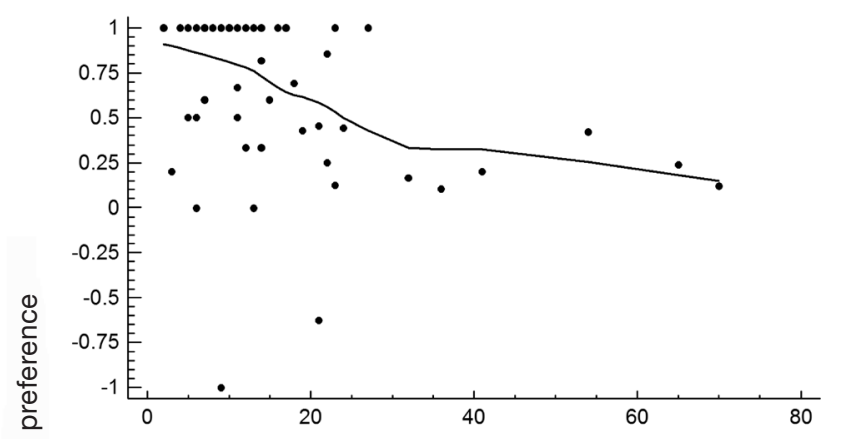

C

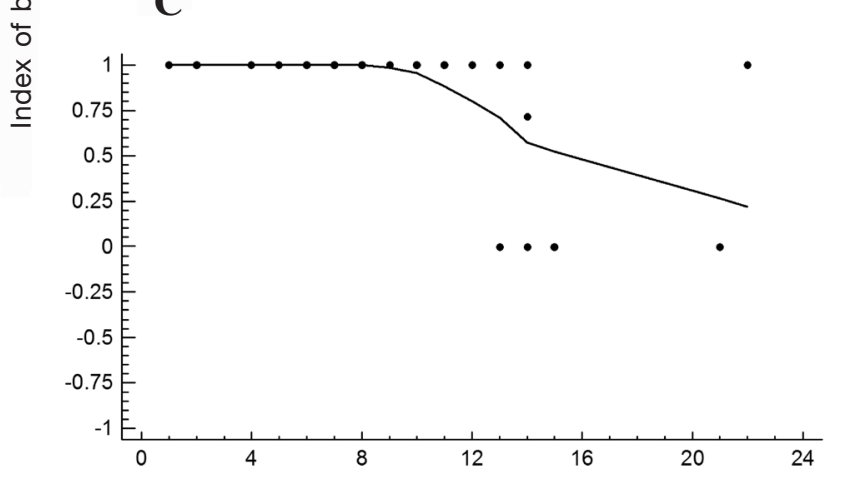

B

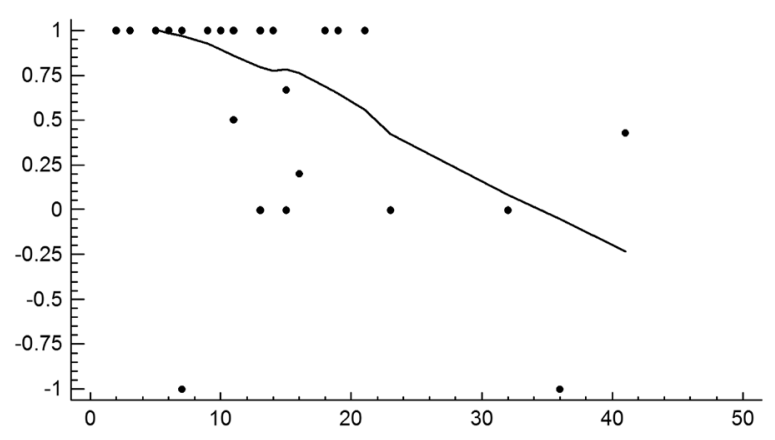

D

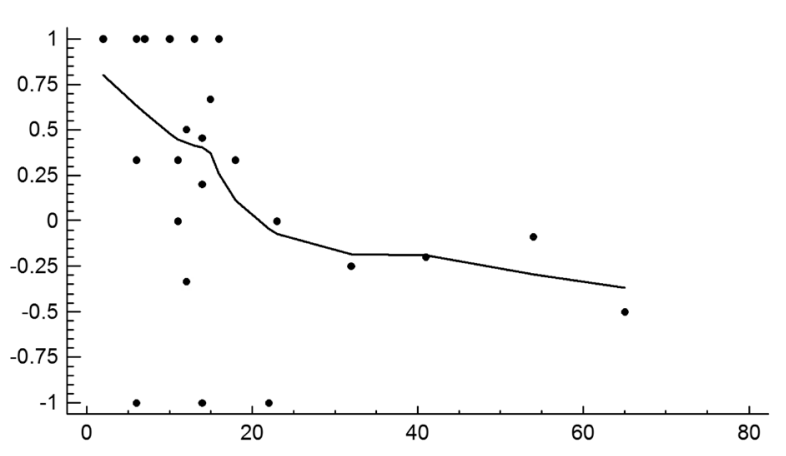

Total number of individuals captures (all species)

Figure 3

Comparison of relationships between index of bait preference and total capture number of all species on individual longline sets deployed in the northern Gulf of Mexico during March and April 2015 for (A) Atlantic sharpnose sharks (Rhizoprionodon terraenovae), (B) blacknose sharks (Carcharhinus acronotus), (C) sandbar sharks (C. plumbeus), and (D) red snapper (Lutjanus campechanus). The black lines represent locally weighted regression lines (determined through application of locally weighted scatterplot smoothing).

duce bycatch rates of sharks. Watson et al. (2005) and Gilman et al. (2007) examined bycatch of blue sharks in pelagic longline fisheries and found that catch rates of this species declined when mackerel were used as bait. Similarly, Foster et al. (2012) found the use of Atlantic mackerel as bait to decrease bycatch of blue sharks; however, they also indicated that hooks baited with Atlantic mackerel were more efficient at capturing porbeagles (Lamna nasus) and shortfin makos (Isurus oxyrinchus).

Cortés (1999) presented an exhaustive literature review of the diets of 149 shark species and found that the diet of blue sharks was dominated by cephalopods (49.4\%). By comparison, teleost fish species composed $55-98.2 \%$ of the diets of Atlantic sharpnose sharks, blacknose sharks, porbeagles, sandbar sharks, scalloped hammerheads, and shortfin makos (Cortés, 1999). The 2 shark species that we examined and that do not have a primarily piscivorous diet, according to Cortés (1999), were the tiger shark and the smooth dogfish. The diet of tiger sharks was primarily composed of teleost fish species $(35.4 \%)$, and sea turtles $(23.8 \%)$, whereas crustaceans $(64.3 \%)$ and teleost fish species (16.6\%) dominated the diet of smooth dogfish. Cephalopods were reported by Cortés (1999) to constitute $0.0-15.5 \%$ of the diets of the shark species we captured. The results of our study, combined with those of Watson et al. (2005), Gilman et al. (2007), and Foster et al. (2012), indicate that, despite being frequently characterized as opportunistic (e.g., Strasburg, 1958; Lowe et al., 1996), sharks, when presented with a choice between a bait that is a common prey item and one that is not a significant dietary component, will actively select the former.

Although not statistically significant, the catch rate of clearnose skates was 2.7 times higher on hooks with northern shortfin squid than on hooks with Atlantic mackerel, indicating a strong preference for the former. This result was similar to the findings of Ariz et al. (2006) and Coelho et al. (2012), who found that batoids, more specifically ray species, captured on long- 
line gear are caught at a higher rate on hooks baited with northern shortfin squid than on hooks baited with Atlantic mackerel. Ebert and Bizzarro (2007) showed that the clearnose skate has a diverse diet, with approximately $21 \%$ fish and less than $1 \%$ squid species as prey items reported in stomach contents. However, Schwartz (1996) found that the fish component of the diet of clearnose skates was composed of small-bodied fish species, such as the striped anchovy (Anchoa hepsetus), Atlantic croaker (Micropogonias undulatus), spot (Leiostomus xanthurus), and blackcheek tonguefish (Symphurus plagiusa). This finding indicates that a limited gape size resulted in more clearnose skates being captured on hooks with northern shortfin squid because that bait type is more malleable and, therefore, more easily manipulated than Atlantic mackerel.

Among teleosts, no consistent trend in preference for one bait type over another was found. For example, red snapper and tilefish showed no significant preference for either bait type; however, red drum had a significant preference for northern shortfin squid. Conversely, although not statistically significant, there was an obvious trend with yellowedge grouper toward a preference for Atlantic mackerel. The lack of bait preference shown by red snapper and tilefish was expected because both species are widely reported to be omnivorous and opportunistic (e.g., Steimle et al., 1999; Gallaway et al., 2009; Moser et al. ${ }^{2}$ ). Yellowedge grouper have been reported to feed primarily on brachyuran crab and teleost fish species (Heemstra and Randall, 1993); therefore, the trend toward a preference for hooks baited with Atlantic mackerel was not unexpected.

In contrast, the preference for bait of northern shortfin squid exhibited by red drum was not clearly related to the known diet of this species. The results of a number of studies indicate that red drum forage on a diverse group of prey, including invertebrate and fish species and that their prey varies depending on life stage, habitat, and season (e.g., Overstreet and Heard, 1978; Scharf and Schlicht, 2000). For example, Boothbly and Avualt (1971) examined the stomach contents of red drum sampled within a coastal marsh system along the coast of Louisiana and determined that crustaceans dominated the diet from late spring through fall but fish species became more important during colder months. As pointed out by Overstreet and Heard (1971) and Scharf and Schlicht (2000), dietary shifts likely were related to seasonally mediated changes in abundance of prey species. However, Matlock (1987) reported that, in general, adult red drum consume more individuals that are fish species than individuals that are invertebrate species. Therefore, the preference that red drum showed for the northern shortfin squid in

\footnotetext{
2 Moser, J. G., Jr., A. G. Pollack, G. W. Ingram Jr., C. T. Gledhill, T. A. Henwood, and W. B. Driggers III. 2012. Developing a survey methodology for sampling red snapper, Lutjanus campechanus, at oil and gas platforms in the northern Gulf of Mexico. Southeast Data, Assessment, and Review, SEDAR31-DW26, 23 p. [Available from website.]
}

our study cannot be explained on the basis of dietary composition reported in the literature because Atlantic mackerel would have been the expected preferred bait type. Although the most likely explanation is gape limitation, another possible explanation is that red drum were outcompeted for hooks baited with Atlantic mackerel and opportunistically fed on northern shortfin squid. However, it does not appear that red drum were outcompeted because all sets where red drum were captured had relatively low catch rates of other fish species.

There was a clear decrease in bait preference with increasing total catch rates for Atlantic sharpnose, blacknose, and sandbar sharks. This trend was most obvious for sandbar sharks: on sets with less than 13 other captured individuals, regardless of species, $100 \%$ of sandbar sharks were caught on hooks baited with Atlantic mackerel. At catch rates of 13 or more individuals, regardless of species, on a set, the likelihood that sandbar sharks would be captured on hooks baited with northern shortfin squid increased. This decrease in bait preference indicates that Atlantic sharpnose, blacknose, and sandbar sharks become more opportunistic when in the presence of competitors or that fewer hooks baited with Atlantic mackerel were available later in the set (as a result of depredation of preferred bait types or a captured fish occupying a hook) and late arriving individuals did not have an equal number of both bait types from which to choose.

As total catch rates increased, the trend of Atlantic sharpnose, blacknose, and sandbar sharks moved toward no preference for a particular bait type (i.e., IBP approached 0) and the trend of red snapper moved toward a preference for northern shortfin squid (i.e., IBP $<0)$. This result indicates that sharks were still actively selecting hooks baited with Atlantic mackerel despite more hooks baited with northern shortfin squid being available. Conversely, the trend in bait preference of red snapper at increasing total catch rates indicates that they were feeding opportunistically on the most abundant bait type available. This latter point can be more clearly demonstrated by comparing the IBP values of the Atlantic sharpnose shark with those of the red snapper. On longline sets with greater than 25 individuals captured, IBP values were exclusively greater than 0 for the Atlantic sharpnose shark and less than 0 for red snapper. Another possible explanation for the shift toward a reduced preference for Atlantic mackerel at high catch rates could be differences in retention rates of the 2 bait types as hook soak time increased. However, there was no significant difference in the distribution of soak times for hooks retrieved with whole bait present for each bait type.

Beyond species-specific dietary preferences, it is possible that differences in foraging strategies among the species we examined, at least in part, led to differences in catch rates of fish species on the 2 bait types. All shark species that we examined are active, roaming predators. Speed et al. (2010) estimated that the home range (excluding seasonal migrations) of small-bodied 
coastal shark species that are not reef obligate or constrained within a bounded area (e.g., bay or estuary) can be up to $100 \mathrm{~km}^{2}$. For example, through acoustic monitoring, Heupel et al. (2006) determined the mean home range of the bonnethead (Sphyrna tiburo) was $8.31 \mathrm{~km}^{2}$; however, some individuals used areas of up to approximately $74 \mathrm{~km}^{2}$. Larger-bodied species, such as the tiger shark, have been documented to have vast home ranges, on the order of 1000 s of square kilometers (Heithaus et al., 2007).

Conversely, most of the teleosts that we captured, with the exception of the red drum, are relatively sedentary and have a high degree of site fidelity in offshore waters to discrete structures, such as lumps and depressions (e.g., Able et al., 1993; Gallaway et al., 2009). For example, Jones et al. (1989) documented tilefish and yellowedge grouper in the western Gulf of Mexico occupying discrete burrows with openings ranging from 0.25 to $8 \mathrm{~m}$ wide. Able et al. (1982) hypothesized that these structures serve as refuge from predators, and Jones et al. (1989) suggested that individuals have long-term fidelity to specific burrows. Although it is unknown how far these individuals move from their burrows to forage, the aforementioned studies all indicate that, in contrast with coastal shark species, most teleost species that we examined remain in relatively close proximity to a specific location. Therefore, it is possible that the teleosts that exhibited this behavior in our study were attracted to bait on the basis of proximity rather than preference.

In contrast, because shark species rely, in part, on chemotaxis to locate prey from a distance (e.g., Sheldon, 1911; Løkkeborg et al., 2014), it is possible that the area of bait influence was greater for Atlantic mackerel than for northern shortfin squid and led to sharks homing in more frequently on hooks baited with Atlantic mackerel. Chemotaxis, however, is unlikely to have affected bait preference given the relatively close gangion spacing ( $18 \mathrm{~m}$ apart), diffusion and mixing of scent plumes from individual baits with increasing distance from the gear, and the setting of gear parallel to the axis of a current that resulted in a single plume of odorants from both Atlantic mackerel and northern shortfin squid. Therefore, given that these 2 species have significantly different relative concentrations of low-molecular-weight metabolites that are known attractants or stimulants of feeding behavior in fish species (Carr et al., 1996), it is more likely that higher catch rates of most shark species on hooks baited with Atlantic mackerel was a result of preference and not the area of bait influence.

A potential criticism of our study is that we used alternating bait types on each longline set rather than making comparisons on the basis of single-bait sets. Although numerous bait preference studies have used an alternating bait design similar to the one in our study (e.g., Broadhurst and Hazin, 2001; Woll et al., 2001; Yokota et al., 2009), it was suggested by Watson et al. (2005) and Foster et al. (2012) that the use of alternating bait types can bias results because of a po- tential interaction effect of bait types. Both Watson et al. (2005) and Foster et al. (2012) examined effects of bait and hook type on catch rates of epipelagic organisms caught on pelagic longline gear and therefore they focused on highly mobile species, such as sea turtles, sharks, swordfish, and tunas, that occupy a single habitat (epipelagic zone).

Conversely, we used bottom longline gear in a highly dynamic area in terms of prey density, foraging behaviors of target species, currents, depth, dissolved oxygen, salinity, temperature, turbidity, substrate types, and patchy habitats. Therefore, because many of these variables affect feeding behavior and the ability of fish species to locate baited hooks (Løkkeborg et al., 2014), we believe the use of alternating bait types is justified and best suited to answer the questions we were addressing. Had we used a single-bait approach, we would have needed to account for each of the biotic and abiotic variables for individual longline sets. However, although we acknowledge that the use of alternating bait types could have introduced a potential bait interaction effect, we did expose an equal number of both bait types to all conditions encountered, thereby limiting the number of potentially biasing factors to one.

Additionally, several of the species we encountered are infrequently captured and occur in large aggregations. For example, of the 79 little gulper sharks collected, $62 \%$ were caught on 2 sets. Further, although little gulper sharks are infrequently captured in shelf waters of the northern Gulf of Mexico, when present, they are found in large schools (senior author, personal observ.). Had single-bait sets been used and had a set occurred in proximity to a school of little gulper sharks, the resulting data would be indicative of the high density of little gulper sharks in the area and not of a preference for a specific bait type.

Ward et al. (2004) examined the theoretical effect of hook soak time on pelagic longline catches in the Pacific Ocean and determined that catch rates can be affected by, among other issues, baits falling off during deployment of longline sets, by deterioration that results in baits falling off hooks, or by a time-related reduction in the degree of attraction. Godin et al. (2012), in a metadata analysis, stated that the catch of sharks, in general, was reduced when Atlantic mackerel were used as bait. They went on to reason that squid, when compared to mackerel, was a more effective bait because it remains on hooks longer, does not deteriorate as rapidly, and does not lose its attraction properties over time.

Although we were not able to quantify the attractant properties of the 2 bait types, our results are in direct opposition to those of Godin et al. (2012) in that we found both bait types were retained on hooks equally and that bait damage or loss was greater for hooks baited with northern shortfin squid. The disparity in the 2 studies is likely attributable to the data sources of Godin et al. (2012) primarily reporting catch of blue sharks and to differences in hook soak times among studies. For example, Godin et al. (2012) included fish- 
eries-dependent data sources, and commercial longline gear is generally set for much longer periods (e.g., >8 h) than the 1-4 h we allowed gear to soak. Future work should examine the "endurance" of the 2 bait types beyond the maximum hook soak time of $4 \mathrm{~h}$ in our study as well as the effect of hook soak time on catch rates and bait performance.

Our results, as well as those of the aforementioned studies, indicate that species-specific catch rates can be impacted significantly by the type of bait used. Therefore, an understanding of species-specific bait preferences of target and bycatch species is imperative, a point also highlighted by Coelho et al. (2012). Furthermore, because ontogenetic (e.g., Wells et al., 2008) and seasonal shifts (e.g., Boothby and Avault, 1971) in dietary preferences are well established among fish species, it will be necessary to identify preferences across all life stages and seasons so that no one stage is adversely affected or seasonally vulnerable. Future research will be needed to determine whether the use of a single bait type (i.e., northern shortfin squid) effectively will reduce the catch rates of shark species in the Gulf of Mexico snapper and grouper bottom longline fishery or whether sharks will opportunistically feed on a single bait type at the same rate as a preferred bait type in the absence of choice.

\section{Acknowledgments}

We thank the crew of the NOAA Ship Oregon II, S. Garner, M. Hendon, N. Hopkins, J. Lewis, J. McKinney, J. Moser, B. Noble, B. Prohaska, K. Rademacher, and T. Wallace for assistance in the collection of samples.

\section{Literature cited}

Able, K. W., C. B. Grimes, R. A. Cooper, and J. R. Uzmann. 1982. Burrow construction and behavior of the tilefish, Lopholatilus chamaeleonticeps, in Hudson Submarine Canyon. Environ. Biol. Fish. 7:199-205. Article

Able, K. W., C. B. Grimes, R. S. Jones, and D. C. Twichell. 1993. Temporal and spatial variation in habitat characteristics of tilefish (Lopholatilus chamaeleonticeps) off the east coast of Florida. Bull. Mar. Sci. 53:1013-1026.

Ariz, J., A. Delgado de Molina, M. L. Ramos, and J. C. Santana. 2006. Check list and catch rate data by hook type and bait for bycatch species caught by Spanish experimental longline cruises in the south-western Indian Ocean during 2005. Indian Ocean Tuna Commission, IOTC2006-WPBy-04, 10 p.

Beerkircher, L. R., E. Cortés, and M. Shivji.

2002. Characteristics of shark bycatch observed on pelagic longline off the southeastern United States, 1992 2000. Mar. Fish. Rev. 64(4):40-49.

Boothby, R. N, and J. W. Avault Jr.

1971. Food habits, length-weight relationship, and condition factor of the red drum (Sciaenops ocellata) in southeastern Louisiana. Trans. Am. Fish. Soc. 100:290-295. Article
Broadhurst, M. K., and F. H. V. Hazin.

2001. Influence of type and orientation of bait on catches of swordfish (Xiphias gladius) and other species in an artisanal sub-surface longline fishery off northeastern Brazil. Fish. Res. 53:169-179. Article

Carr, W. E. S., J. C. Netherton III, R. A. Gleeson, and C. D. Derby.

1996. Stimulants of feeding behavior in fish: analyses of tissues of diverse marine organsims. Biol. Bull. 190:149-160. Article

Carruthers, E. H., J. D. Neilson, and S. C. Smith.

2011. Overlooked bycatch mitigation opportunities in pelagic longline fisheries: soak time and temperature effects on swordfish (Xiphias gladius) and blue shark (Prionace glauca) catch. Fish. Res. 108:112-120. Article

Coelho, R., M. N. Santos, and S. Amorim.

2012. Effects of hook and bait on targeted and bycatch fishes in an equatorial Atlantic pelagic longline fishery. Bull. Mar. Sci. 88:449-467. Article

Cortés, E.

1999. Standardized diet compositions and trophic levels of sharks. ICES J. Mar. Sci. 56:707-717. Article

Ebert, D. A., and J. J. Bizzarro.

2007. Standardized diet compositions and trophic levels of skates (Chondrichthyes: Rajiformes: Rajoidei). Environ. Biol. Fish. 80:221-237. Article

Foster, D. G., S. P. Epperly, A. K. Shah, and J. W. Watson.

2012. Evaluation of hook and bait type on the catch rates in the western North Atlantic Ocean pelagic longline fishery. Bull. Mar. Sci. 88:529-545. Article

Francis, M. P., L. H. Griggs, and S. J. Baird.

2001. Pelagic shark bycatch in the New Zealand tuna longline fishery. Mar. Freshw. Res. 52:165-178. Article

Gallaway, B. J., S. T. Szedlmayer, and W. J. Gazey.

2009. A life history review for red snapper in the Gulf of Mexico with an evaluation of the importance of offshore petroleum platforms and other artificial reefs. Rev. Fish. Sci. 17:48-67. Article

Gilman, E., D. Kobayashi, T. Swenarton, N. Brothers, P. Dalzell, and I. Kinan-Kelly.

2007. Reducing sea turtle interactions in the Hawaiibased longline swordfish fishery. Biol. Conserv. 139:1928. Article

Gilman, E., S. Clarke, N. Brothers, J. Alfaro-Shigueto, J. Mandelman, J. Mangel, S. Petersen, S. Piovano, N. Thomson, P. Dalzell, et al.

2008. Shark interactions in pelagic longline fisheries. Mar. Policy 32:1-18. Article

Godin, A. C., J. K. Carlson, and V. Burgener.

2012. The effect of circle hooks on shark catchability and at-vessel mortality rates in longline fisheries. Bull. Mar. Sci. 88:469-483. Article

Gulak, S. J. B., M. P Enzenauer, and J. K. Carlson.

2013. Characterization of shark and reef fish bottom longline fisheries: 2012. NOAA Tech. Memo. NMFS-SEFSC$652,42 \mathrm{p}$.

Heemstra, P. C., and J. E. Randall.

1993. FAO species catalogue, vol. 16. Grouper of the world (family Serranidae, subfamily Epinephelinae): an annotated and illustrated catalogue of the grouper, rockcod, hind, coral grouper and lyretail species known to date. FAO Fisheries Synopsis 125, 382 p. FAO, Rome.

Heithaus, M. R., A. J. Wirsing, L. M. Dill, and L. I. Heithaus. 2007. Long-term movements of tiger sharks satellite- 
tagged in Shark Bay, Western Australia. Mar. Biol. 151:1455-1461. Article

Heupel, M. R., C. A. Simpfendorfer, A. B. Collins, and J. P Tyminski.

2006. Residency and movement patterns of bonnethead sharks, Sphyrna tiburo, in a large Florida estuary. Environ. Biol. Fish. 76:47-67. Article

Jones, R. S., E. J. Gutherz, W. R. Nelson, and G. C. Matlock.

1989. Burrow utilization by yellowedge grouper, Epinephelus flavolimbatus, in the northwestern Gulf of Mexico. Environ. Biol. Fish. 26:277-284. Article

Løkkeborg, S., S. I. Siikavuopio, O. B. Humborstad, A. C. UtnePalm, and K. Ferter.

2014. Towards more efficient longline fisheries: fish feeding behaviour, bait characteristics and development of alternative baits. Rev. Fish Biol. Fish. 24:985-1003. Article

Lowe, C. G., B. M. Wetherbee, G. L. Crow, and A. L. Tester.

1996. Ontogenetic dietary shifts and feeding behavior of the tiger shark, Galeocerdo cuvier, in Hawaiian waters. Environ. Biol. Fish. 47:203-211. Article

Matlock, G. C.

1987. The life history of the red drum. In Manual of red drum aquaculture (G. W. Chamberlain, R. J. Miget, and M. G. Haby, eds.). p. 1-47. Texas Agricultural Extension Service and Sea Grant College Program, Texas A\&M University, College Station, TX.

Overstreet, R. M., and R. W. Heard.

1978. Food of the red drum, Sciaenops ocellatus, from the Mississippi Sound. Gulf Res. Rep. 6:131-135. Article

Prytherch, H. F.

1983. A descriptive survey of the bottom longline fishery in the Gulf of Mexico. NOAA Tech. Memo. NMFS-SEFC-122, $33 \mathrm{p}$.

Rey, J. C., and R. Muñoz-Chápuli.

1991. Relation between hook depth and fishing efficiency in surface longline gear. Fish. Bull. 89:729-732.

Robbins, W. D., V. M. Peddemors, and S. J. Kennelly.

2011. Assessment of permanent magnets and electropositive metals to reduce the line-based capture of Galapagos sharks, Carcharhinus galapagensis. Fish. Res. 109:100-106. Article

Rogers, A.

1920. Industrial uses for the shark and porpoise. J. Am. Leather Chem. Assoc. 15:241-244.

Scharf, F. S., and K. K. Schlicht.

2000. Feeding habits of the red drum (Sciaenops ocellatus) in Galveston Bay, Texas: seasonal diet variation and predator-prey size relationships. Estuaries 23:128-139. Article

Schwartz, F. J.

1996. Biology of the clearnose skate, Raja eglanteria, from North Carolina. Fla. Sci. 59:82-95.
Scott-Denton, E., P. F. Cryer, J. P. Gocke, M. R. Harrelson, D. L. Kinsella, J. R. Pulver, R. C. Smith, and J. Williams.

2011. Descriptions of the U.S. Gulf of Mexico reef fish bottom longline and vertical line fisheries based on observer data. Mar. Fish. Rev. 73(2):1-26.

Sheldon, R. E.

1911. The sense of smell in selachians. J. Exp. Zool. 10:51-62. Article

Speed, C. W., I. C. Field, M. G. Meekan, and C. J. A. Bradshaw.

2010. Complexities of coastal shark movements and their implications for management. Mar. Ecol. Prog. Ser. 408:275-293. Article

Strasburg, D. W.

1958. Distribution, abundance, and habits of pelagic sharks in the central Pacific Ocean. Fish. Bull. 58:335-361.

Steimle, F. W., C. A. Zetlin, P. L. Berrien, D. L. Johnson, and S. Chang.

1999. Tilefish, Lopholatilus chamaeleonticeps, life history and habitat characteristics. NOAA Tech. Memo. NMFS$\mathrm{NE}-152,30 \mathrm{p}$.

Walsh, W. A., K. A. Bigelow, and K. L. Sender.

2009. Decreases in shark catches and mortality in the Hawaii-based longline fishery as documented by fishery observers. Mar. Coast. Fish. 1:270-282.

Ward, P., R. A. Myers, and W. Blanchard.

2004. Fish lost at sea: the effect of soak time on pelagic longline catches. Fish. Bull. 102:179-195.

Ward, P, E. Lawrence, R. Darbyshire, and S. Hindmarsh.

2008. Large-scale experiment shows that nylon leaders reduce shark bycatch and benefit pelagic longline fishers. Fish. Res. 90:100-108. Article

Watson, J. W., S. P. Epperly, A. K. Shah, and D. G. Foster.

2005. Fishing methods to reduce sea turtle mortality associated with pelagic longlines. Can. J. Fish. Aquat. Sci. 62:965-981. Article

Watson, J. T., T. E. Essington, C. E. Lennert-Cody, and M. A. Hall.

2009. Trade-offs in the design of fishery closures: management of silky shark bycatch in the eastern Pacific Ocean tuna fishery. Conserv. Biol. 23:626-635. Article

Woll, A. K., J. Boje, R. Holst, and A. C. Gundersen.

2001. Catch rates and bait selectivity in longline fishery for Greenland halibut (Reinhardtius hippoglossoides, Walbaum) at East Greenland. Fish. Res. 51:237-246. Article

Wells, R. J. D., J. H. Cowan Jr., and B. Fry.

2008. Feeding ecology of red snapper Lutjanus campechanus in the northern Gulf of Mexico. Mar. Ecol. Prog. Ser. 361:213-225. Article

Yokota, K., M. Kiyota, and H. Okamura.

2009. Effect of bait species and color on sea turtle bycatch and fish catch in a pelagic longline fishery. Fish. Res. 97:53-58. Article 